\title{
Immunohistochemical Characteristics of Cystic Odontogenic Lesions: A Comparative Study
}

\author{
Kistik Odontojenik Lezyonların İmmünohistokimyasal Özellikleri: \\ Karşılaştırmalı Bir Çalışma
}

\author{
Ayhan ÖZCAN, İbrahim YAVAN, Ömer GÜNHAN \\ Department of Pathology, Gülhane Military Medical Academy, School of Medicine, ANKARA, TURKEY
}

\begin{abstract}
Objective: Cystic ameloblastoma, keratocystic odontogenic tumor, dentigerous cyst, and radicular cyst are the most commonly encountered cystic odontogenic lesions. The aim of this study was to investigate the expressions of survivin, E-cadherin, CD138, and $\mathrm{CD} 38$ in these lesions and their potential diagnostic usage.
\end{abstract}

Material and Method: A total of 20 cases, consisting 5 radicular cysts, 5 dentigerous cysts, 5 keratocystic odontogenic tumors and 5 cystic ameloblastomas were included in our series. For all cases, sections from the selected blocks were stained against the antibodies for survivin, E-cadherin, CD138, and CD38 on an automated device.

Results: All cystic ameloblastomas and keratocystic odontogenic tumors showed diffuse and strong nuclear survivin expression. No specific survivin immunoreactivity was observed in the dentigerous and radicular cysts. E-cadherin expression was stronger in all dentigerous cysts and radicular cysts when compared to others. CD138 expression in stromal cells was prominent in cystic ameloblastomas, but gradually decreased in the other three lesions. All cases were negative for CD38.

Conclusion: In the present study, loss of E-cadherin expression in epithelial cells, strong CD138 expression in stromal cells and strong nuclear survivin expression both in epithelial and stromal cells in cystic ameloblastomas and keratocystic odontogenic tumors were the most remarkable findings. These findings are also reinforced by the studies suggesting their role in the aggressiveness and pathogenesis of these tumors.

Key Words: Odontogenic tumors, Odontogenic cysts, Immunohistochemistry

(Turk Patoloji Derg 2015, 31:104-110)

Received : 26.08.2014 Accepted : 11.10.2014

\section{ÖZ}

Amaç: Kistik ameloblastoma, keratokistik odontojenik tümör, dentijeröz kist ve radiküler kist en sık karşılaşılan kistik odontojenik lezyonlardır. Çalışmada bu lezyonlarda survivin, E-cadherin, CD138 ve CD38 ekspresyonları ve bunların potansiyel tanısal kullanımları araştırılmıştır.

Gereç ve Yöntem: Çalı̧̧ma serimiz 5 kistik ameloblastoma, 5 keratokistik odontojenik tümör, 5 dentijeröz kist ve 5 radiküler kist olmak üzere toplam 20 olgudan oluşmaktadır. Bütün olgulara ait seçilmiş bloklardan sağlanan kesitler otomatize bir cihazda survivin, E-cadherin, CD138, and CD38 antikorları ile boyandı.

Bulgular: Kistik ameloblastoma ve keratokistik odontojenik tümörlerin hepsi yaygın ve kuvvetli nükleer survivin ekspresyonu gösterdi. Dentijeröz ve radiküler kistlerde spesifik survivin ekspresyonu gözlenmedi. E-cadherin ekspresyonu diğer lezyonlarla karşılaştırıldığında, dentijeröz ve radiküler kistlerde daha belirgindi. CD138 ekspresyonu kistik ameloblastomalarda stromal hücrelerde daha belirgindi, ancak diğer lezyonlarda giderek azalan oranlardaydı. CD38 olguların hepsinde negatifdi.

Sonuç: Çalışmada, keratokistik odontojenik tümörlerde ve kistik ameloblastomada epitelyal hücrelerde E-cadherin kaybı, stromal hücrelerde kuvvetli CD138 ekspresyonu ve hem epitelyal hem de stromal hücrelerde kuvvetli nükleer survivin ekspresyonu en karakteristik bulgulardır. Bu bulguların bu tür lezyonların patogenezini ve agresif davranışındaki rolünü de gösterecek çalışmalarla güçlendirilmesi gerekmektedir.

Anahtar Sözcükler: Odontojenik tümörler, Odontojenik kistler, İmmünohistokimya
Correspondence: Ayhan ÖZCAN

Gülhane Askeri Tip Akademisi, Patoloji Anabilim Dalı

General Tevfik Sağlam Caddesi, 06018 Etlik, Ankara, TURKEY

E-mail: aozcan@gata.edu.tr Phone: + 903123043706 


\section{INTRODUCTION}

Cystic ameloblastoma (CA), keratocystic odontogenic tumor (KCOT), dentigerous cyst (DC), and radicular cyst (RC) are the most commonly encountered cystic odontogenic lesions. Among cystic odontogenic lesions, ameloblastoma and keratocystic odontogenic tumors (KCOTs) are regarded as benign, but they can be locally invasive with extensive bone destruction.

Survivin, which is an inhibitor of apoptosis protein (IAP), is a bifunctional protein that suppresses apoptosis by inhibiting caspase activation while regulating cell division and promoting cell proliferation, differentiation, and angiogenesis at the same time (1). Survivin is expressed in many various human malignancies including hepatocellular carcinoma, colorectal cancer, lung cancer, pancreatic and kidney cancers, and osteosarcoma (2-7). Survivin plays an important role both in initiation and progression of these tumors (2-7). Over-expression of survivin is suggested to be associated with aggressive behavior in KCOTs and ameloblastomas $(8,9)$.

E-cadherin is the major $\mathrm{Ca}^{2+}$ dependent cell adhesion molecule of epithelial cells and plays a role in morphogenesis and the maintenance of the integrity of epithelial cells (10, 11). E-cadherin expression is inversely proportional to the degree of differentiation in various cancers. Loss of E-cadherin-mediated cell-cell adhesion is associated with the progression of many carcinomas including breast, bladder, gastric, squamous head and neck cancers (12-15). Loss of E-cadherin expression in the epithelium of invasive squamous cell carcinomas and squamous intraepithelial lesions of the uterine cervix and skin reduces the density of Langerhans cells, and thus compromises the capacity of dendritic cells to recognize tumor antigens (16-18).

CD138 and CD38 have been widely used as plasma cells markers in hematopoetic malignancies $(19,20)$. CD138, also known as syndecan 1 , is a transmembrane heparin sulfate proteoglycan. CD138 (syndecan 1 is a highly expressed antigen in epithelial cells. However, expressions of other syndecans, syndecan 2 in mesothelial, endothelial, neural and fibroblastic cells, syndecan 3 in neural cells, and syndecan 4 in epithelial and fibroblastic cells, are known not to be high in epithelial cells. CD138 (syndecan 1) is a receptor for extracellular matrix proteins such as collagen, fibronectin and thrombospondin, and participates in cell proliferation, cell migration, and cell interactions $(19,20)$. CD138 plays a role in the differentiation of B lymphocytes to plasma cells and is observed in non-neoplastic plasma cells, neoplastic plasma cells in multiple myeloma, and the plasmacytic component in lymphoplasmacytic lymphoma (20). It is also expressed in many solid tumors including breast, colon, lung, prostate, and kidney cancers (2023). It modulates cancer cell proliferation and apoptosis, angiogenesis, tumor invasion, and metastasis (21). Loss of CD138 expression is associated with increased invasive and metastatic potential in carcinomas (22). It has been suggested that $\mathrm{CD} 138$ is essential for the maintenance of epithelial morphology and control of cytoskeletal organization and its expression has prognostic value in clinical outcome of ameloblastomas and odontogenic cysts (24).

CD38 is a transmembrane molecule and found on the surface of many immune cells including CD4+, CD8+, and $B$ lymphocytes, in addition to natural killer cells. CD38 also functions in cell adhesion, signal transduction and calciumdependent cell signaling pathways $(25,26)$.

The differential diagnosis in odontogenic cystic lesions and the understanding of their pathogenesis are essential for their accurate diagnosis and the determination of appropriate treatment modalities. Although there are several studies related to role of these proteins in odontogenic lesions in English literature (8, 9, 18, 24, 27-29), no comparative and comprehensive study, in which the expression of these proteins or adhesion molecules in odontogenic cystic lesions have been evaluated, to our knowledge. Therefore, we aim to evaluate the immunohistochemical expressions of CD138 (syndecan-1), CD38, E-cadherin and survivin in these cystic odontogenic lesions and investigate the potential implications of their expressions among these lesions.

\section{MATERIAL and METHODS}

A total of 20 cases consisting 5 radicular cysts (RCs), 5 dentigerous cysts (DCs), 5 keratocystic odontogenic tumors (KCOTs) and 5 cystic ameloblastomas (CAs) were included in this study. For all cases, sections from the selected blocks were stained against the antibodies for survivin (Neomarkers, Labvision, Ab-2, clone 4F7, 1/100 dilution, avidin-biotin-peroxidase), E-cadherin (Dako, Clone NCH-38, 1/100 dilution, avidin-biotin-peroxidase), CD138 (Cell Marqoue, clone B-A38, 1/100 dilution, avidinbiotin-peroxidase), and CD38 (Novocastra, clone NCLCD38-290, 1/100 dilution, avidin-biotin-peroxidase) on an automated device (Ventana, Benchmark XT). The staining intensity was graded and recorded semi-quantitatively as 0 (no staining), $1+$ (weak), 2+ (moderate) and 3+ (strong).

\section{RESULTS}

All staining scores were summarized in Table I.

The features of survivin expression in the cystic odontogenic lesions: All CAs (Figure $1 \mathrm{~A}, \mathrm{~B}$ ) and KCOTs (Figure 1 C,D) showed diffuse and strong nuclear survivin expression in all epithelial and stromal cells with some weak cytoplasmic staining, as well. Epithelial staining in these cases was strongest in basal cell layer. In contrast, weak cytoplasmic and nuclear staining in all epithelial layers with basal cell 
Table I: Immunoprofiles in cystic odontogenic lesions

\begin{tabular}{|c|c|c|c|c|c|c|c|c|c|c|c|c|c|c|}
\hline & \multicolumn{4}{|c|}{ Survivin } & \multicolumn{4}{|c|}{ E-cadherin } & \multicolumn{4}{|c|}{ CD138 (Syndecan-1) } & \multicolumn{2}{|c|}{ CD38 } \\
\hline & \multicolumn{2}{|c|}{$\mathrm{EC}$} & \multicolumn{2}{|c|}{ SC } & \multicolumn{2}{|c|}{ EC } & \multicolumn{2}{|c|}{ SC } & \multicolumn{2}{|c|}{ EC } & \multicolumn{2}{|c|}{ SC } & \multirow{2}{*}{$\begin{array}{l}\text { EC } \\
\underbrace{a}_{a}\end{array}$} & \multirow{2}{*}{$\frac{\text { SC }}{\underbrace{\circ}}$} \\
\hline & $\underbrace{\frac{\partial}{a}}$ & 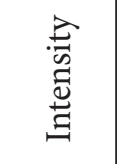 & $\underbrace{d}_{a}$ & 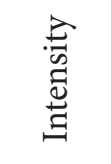 & $\underbrace{\frac{d}{2}}_{a}$ & 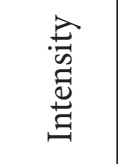 & $\underbrace{\partial}_{a}$ & 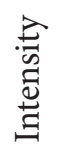 & $\underbrace{d}_{a}$ & 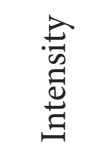 & $\underbrace{o}_{a}$ & 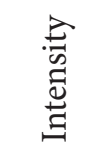 & & \\
\hline $\begin{array}{l}\text { Cystic } \\
\text { ameloblastoma } \\
(n=5)\end{array}$ & $\begin{array}{c}5 / 5 \\
(100)\end{array}$ & $3+$ & $\begin{array}{c}5 / 5 \\
(100)\end{array}$ & $3+$ & $\begin{array}{c}5 / 5 \\
(100)\end{array}$ & $1+/ 2+$ & 0 & 0 & $\begin{array}{c}5 / 5 \\
(100)\end{array}$ & $2+/ 3+$ & $\begin{array}{c}5 / 5 \\
(100)\end{array}$ & $3+$ & 0 & 0 \\
\hline $\begin{array}{l}\text { Keratocystic } \\
\text { odontogenic tumor } \\
(n=5)\end{array}$ & $\begin{array}{c}5 / 5 \\
(100)\end{array}$ & $3+$ & $\begin{array}{c}5 / 5 \\
(100)\end{array}$ & $3+$ & $\begin{array}{c}5 / 5 \\
(100)\end{array}$ & $3+$ & 0 & 0 & $\begin{array}{c}5 / 5 \\
(100)\end{array}$ & $3+$ & $\begin{array}{l}4 / 5 \\
(80)\end{array}$ & $2+/ 3+$ & 0 & 0 \\
\hline $\begin{array}{l}\text { Dentigerous cyst } \\
(n=5)\end{array}$ & $\begin{array}{c}5 / 5 \\
(100) \\
\end{array}$ & $1+/ 2+$ & $\begin{array}{l}4 / 5 \\
(80) \\
\end{array}$ & $1+/ 2+$ & $\begin{array}{c}5 / 5 \\
(100)\end{array}$ & $2+/ 3+$ & 0 & 0 & $\begin{array}{c}5 / 5 \\
(100)\end{array}$ & $2+/ 3+$ & \begin{tabular}{|c|}
$5 / 5$ \\
$(100)$ \\
\end{tabular} & $2+/ 3+$ & 0 & 0 \\
\hline $\begin{array}{l}\text { Radicular cyst } \\
(n=5)\end{array}$ & $\begin{array}{c}5 / 5 \\
(100)\end{array}$ & $1+/ 2+$ & $\begin{array}{c}5 / 5 \\
(100)\end{array}$ & $1+/ 2+$ & $\begin{array}{c}5 / 5 \\
(100)\end{array}$ & $2+/ 3+$ & 0 & 0 & \begin{tabular}{|c|}
$5 / 5$ \\
$(100)$
\end{tabular} & $3+$ & \begin{tabular}{|c|}
$5 / 5$ \\
$(100)$
\end{tabular} & $2+/ 3+$ & 0 & 0 \\
\hline
\end{tabular}

EC: Epithelial cells; SC: Stromal cells

accentuation, and weak cytoplasmic and nuclear staining in the stromal cells were seen in all DCs (Figure $1 \mathrm{E}, \mathrm{F}$ ) and RCs (Figure $1 \mathrm{G}, \mathrm{H}$ ).

The features of E-cadherin expression in the cystic odontogenic lesions: E-cadherin expression was stronger in all DCs (Figure $2 \mathrm{~A}, \mathrm{~B}$ ) and RCs (Figure $2 \mathrm{C}, \mathrm{D}$ ) when compared to CAs (Figure 2 E,F) and KCOTs (Figure 2 G,H). E-cadherin was strongly and equally expressed in all epithelial layers of DCs and RCs. Its expression was strong and only localized in basal and suprabasal cells of KCOTs excluding parakeratotic cells. Weak (1+) E-cadherin expression with suprabasal accentuation $(2+)$ was seen in all lining layer cells of CAs. E-cadherin in stromal cells was recorded as negative in all cases (Table I).

The features of CD138 (syndecan-1) and CD38 expressions in the cystic odontogenic lesions: Cytoplasmic CD138 expression in stromal cells was the most striking finding in CAs (Figure $3 \mathrm{~A}, \mathrm{~B}$ ), but it gradually decreased in DCs (Figure $3 \mathrm{C}, \mathrm{D}$ ), KCOTs (Figure $3 \mathrm{E}, \mathrm{F}$ ) and RCs (Figure $3 \mathrm{G}, \mathrm{H}$ ), respectively. Membranous CD138 expression with basal cell accentuation was seen in all epithelial layers of CAs, DCs and RCs, whereas it was only detected in basal and suprabasal cells of KCOTs. CD 38 was negative in all cases.

\section{DISCUSSION}

Dentigerous cyst (DC) and radicular cyst (RC) are nonneoplastic odontogenic lesions, whereas cystic ameloblastoma (CA) and keratocystic odontogenic tumors (KCOTs) are benign neoplastic odontogenic lesions and they may become locally invasive lesions with extensive bone destruction.
Recently, some studies demonstrated that over-expression of survivin is associated with the more aggressive and invasive phenotype of oral squamous cell carcinoma $(30,31)$. In the study of Kumamoto and Ooya (8), over-expression of survivin was demonstrated in ameloblastomas, and usually detected in many peripheral columnar or cuboidal cells and some central polyhedral cells. Andric et al. demonstrated that nuclear survivin expression was usually evident in basal layer cells of lining epithelial cells of KCOTs and entire epithelial layer was uniformly stained in some cases (9). They also documented that there was no or only weak survivin staining in radicular or apical cysts. Our results were concordant with the results of both studies. However, there was no information regarding survivin expression in stromal cells in them. Presented study also revealed that strong cytoplasmic and nuclear survivin staining in stromal cells was in CAs and KCOTs, but weak staining in DCs and RCs. In the article of de Oliveira et al. (27), survivin staining patterns in DCs and KCOTs is also similar to our observations. Furthermore, some authors hypothesized that cytoplasmic survivin expression is responsible for poor prognosis and for the resistance to therapy in oral squamous cell carcinoma (31). Although effects of nuclear vs. cytoplasmic expression of survivin are still ambiguous, some investigators have reported that predominantly nuclear survivin over-expression is a negative prognostic factor in oropharyngeal squamous cell carcinomas (32). We observed both nuclear and cytoplasmic survivin expression in all cases in varying proportion.

Some authors suggested that loss of E-cadherin expression in neoplastic odontogenic cysts such as CAs and KCOTs reduces the density of Langerhans cells and thus 


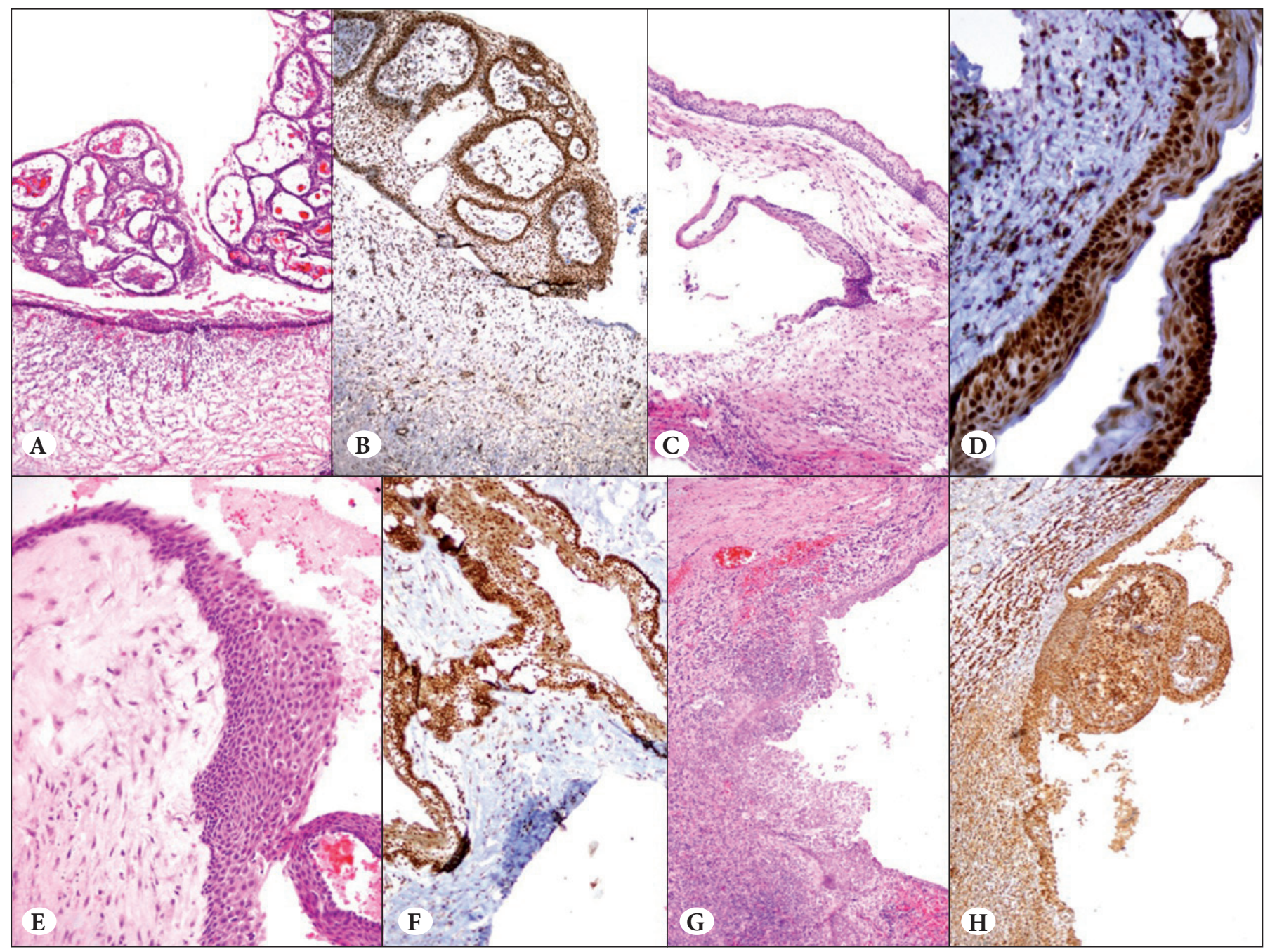

Figure 1: The pattern of survivin expression in neoplastic and non-neoplastic odontogenic cystic lesions: A) H\&E stained section of CA. B) Strong nuclear and weak cytoplasmic survivin expression in all epithelial cell layers with suprabasal accentuation and all stromal cells in CA. C) H\&E stained section of KCOT. D) The staining pattern of survivin in KCOT is similar to CA. E) H\&E stained section of DC. F) Weak nuclear and cytoplasmic staining in all epithelial layers with basal cell accentuation, and weak cytoplasmic and nuclear staining in the stromal cells in DC compared CA and KCOT. G) H\&E stained section of RC. H) The staining pattern of survivin in RC is similar to DC (H\&E, and immunohistochemical stains; x100 for A-C, G, H panels; $\mathrm{x} 200$ for D and E panels).

compromises the capacity of dendritic cells to recognize tumor antigens (16-18). Our study revealed that E-cadherin expression was stronger in non-neoplastic odontogenic cysts (DCs and RCs) rather than neoplastic odontogenic cysts (CAs and KCOTs). These findings support this theory and are similar to the data of previous studies.

Some authors reported that loss of CD138 (syndecan 1) expression in epithelial cells is associated with increased invasive and metastatic potential in some cancers $(22,28)$. Recently, Bologno-Malina et al. demonstrated that solid/ multicystic ameloblastomas had more aggressive biological behavior than the unicystic ameloblastomas (28). In our series, all ameloblastomas were unicystic. In the study of Nadalin et al. (29), CD138 expression was detected in all epithelial layers of KCOTs, RCs and DCs. Our results were similar to the findings of previous studies, but we also observed CD138 expression in the stromal cells. CD138 is normally expressed in the epithelial cells and some mesenchymal cells such as plasma cells and immature B lymphocytes. However, it has been demonstrated that CD138 is expressed by the stromal cells in the some neoplastic and non-neoplastic odontogenic lesions (ameloblastoma, KCOT and DC), and ovarian cancers, as well as plasma cells $(24,33)$. It has also been stated that the expression of CD138 is associated with poor prognosis $(24,33)$. CD138 (syndecan 1) shifting from epithelium to stroma was reported in invasive non-odontogenic solid tumors including breast, prostate, lung, and colon cancers (21). Al-Otaibi et al. showed that CD138 expression was 


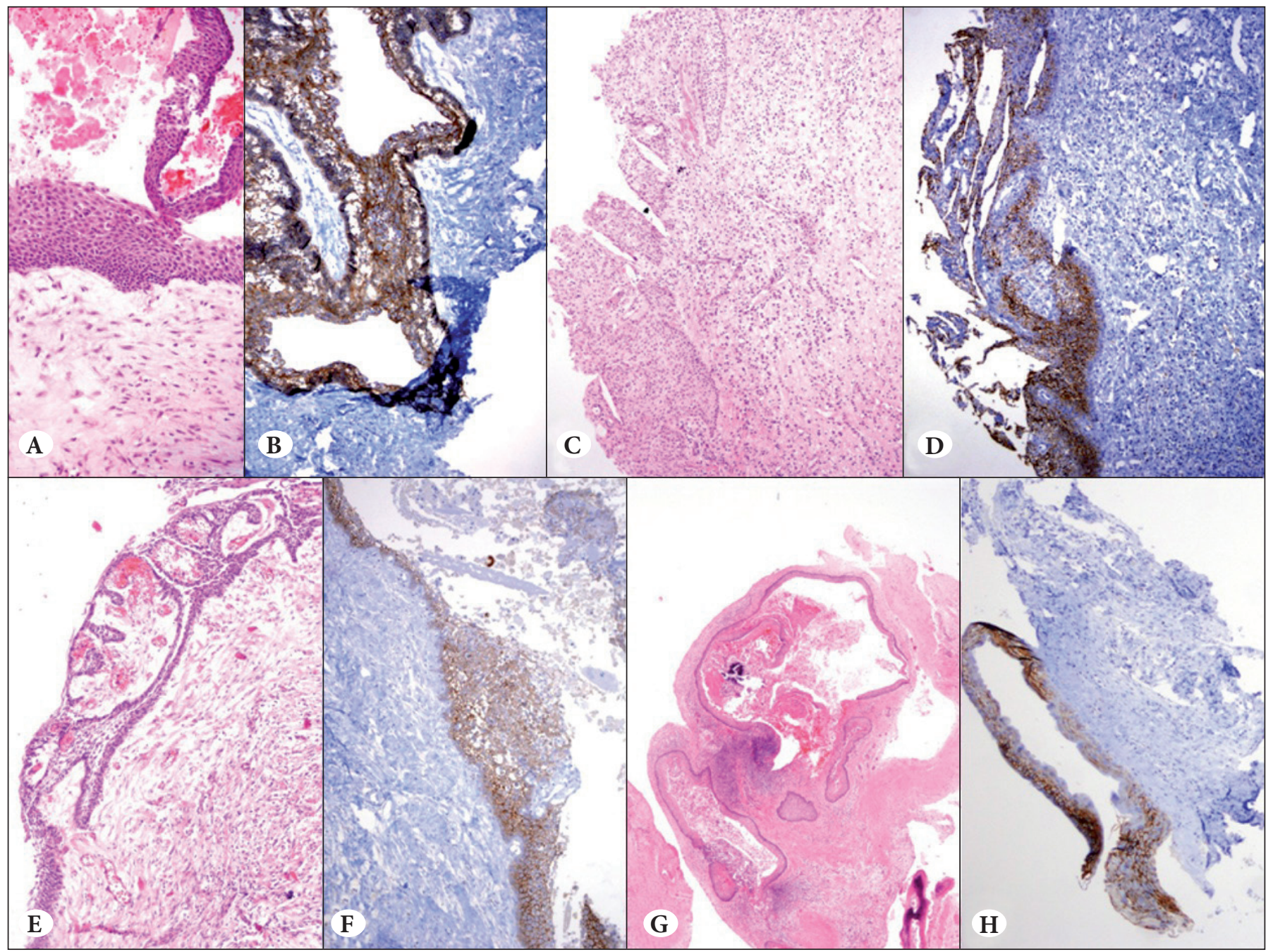

Figure 2: The pattern of E-cadherin expression in neoplastic and non-neoplastic odontogenic cystic lesions: A) H\&E stained section of DC. B) A strong E-cadherin expression in all epithelial cell layers in DC. C) H\&E stained section of RC. D) E-cadherin expression in RC is similar to DC. E) H\&E stained section of CA. F) A weak E-cadherin expression in all epithelial cell layers with suprabasal accentuation in CA. G) H\&E stained section of KCOT. H) E-cadherin expression in KCOT is similar to CA. No E-cadherin expression in stromal cells in the all cases (H\&E and immunohistochemical stains; x100 for E-H panels; x200 for A-D panels).

present in the stromal cells of ameloblastoma, KCOT and DC (24). A role of CD138 expression in the stromal cells and extracellular matrix can be hypothesized as a critical factor for tumorigenesis and local invasiveness of ameloblastomas (24). We also observed CD138 expression in the stromal cell in all cases, especially pronounced in CAs.

Although CD38 has a wider spectrum of B-cell staining than does CD138, there is no expression in neoplastic or non-neoplastic epithelial cells like CD138.

To summarize;

1- A weak E-cadherin expression in epithelial cells, strong CD138 expression in stromal cells, and strong nuclear survivin expressions both in epithelial and stromal cells are characteristic features for CAs and KCOTs.
2- In contrast, a strong E-cadherin expression in epithelial cells, weak CD138 expression in stromal cells, and weak nuclear survivin expressions both in epithelial and stromal cells are characteristic features for DCs and RCs.

3- Although stromal cells in all cases are expressed CD138 and survivin in varying rates, E-cadherin is not expressed by stromal cells in all cases.

4- CD38 is negative in all cases and is not a useful marker in cystic odontogenic lesions.

An immunohistochemical panel consisting of survivin, E-cadherin, and CD138 excluding CD38 antibody may be useful in the diagnosis of cystic odontogenic lesions. These findings are also reinforced by the studies suggesting their role in the aggressiveness and pathogenesis of these tumors. 


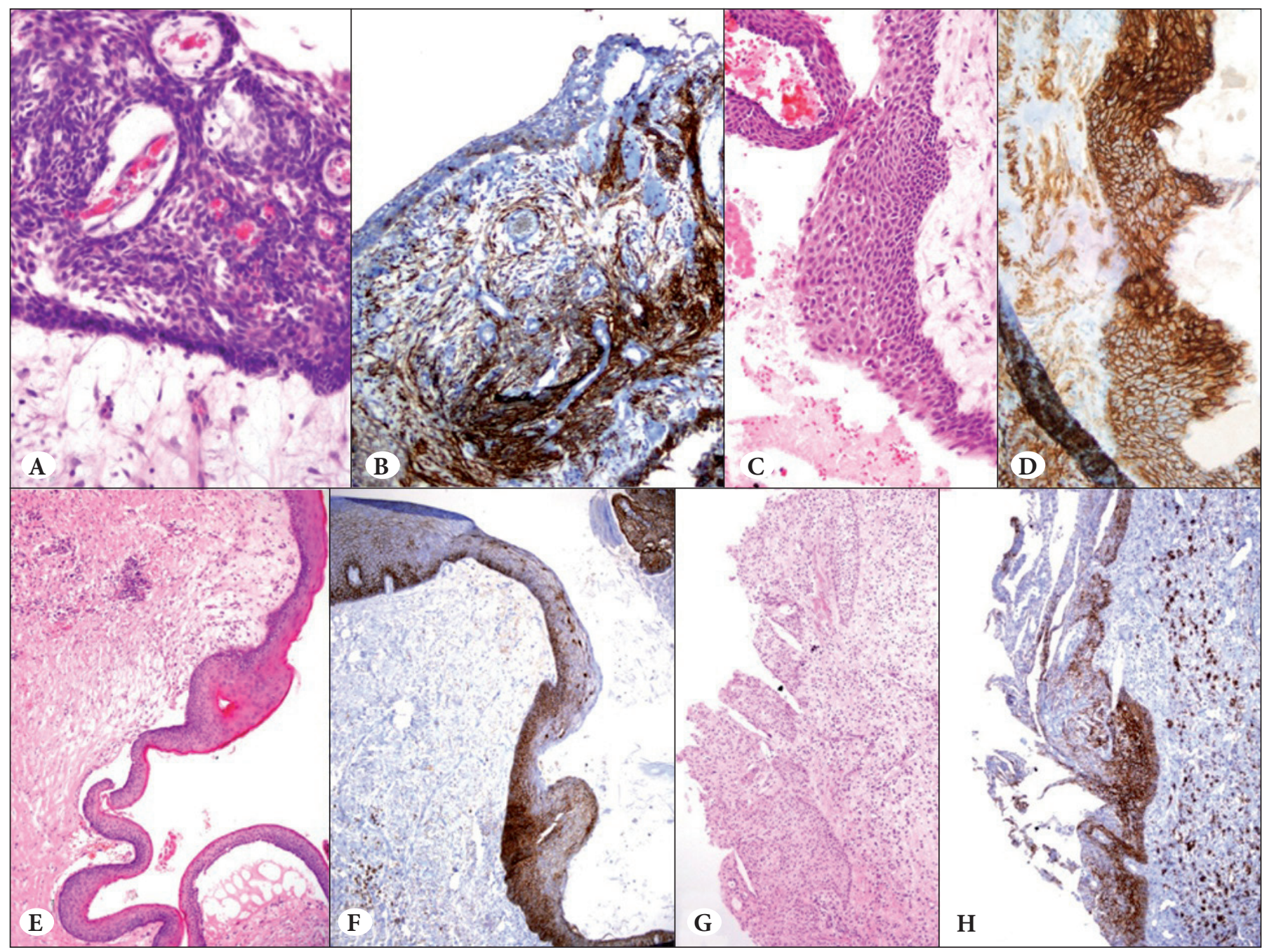

Figure 3: The pattern of CD138 (syndecan 1) expression in neoplastic and non-neoplastic odontogenic cystic lesions: A) H\&E stained section of CA. B) Strong cytoplasmic CD138 expression in stromal cells in CA. C) H\&E stained section of DC. D) Strong membranous CD138 expression in epithelial cells in DC. The cytoplasmic CD138 expression in the stromal cells in DC is weaker compared CA. E) H\&E stained section of KCOT. F) Strong membranous CD138 expression in only basal and suprabasal cells, and weak cytoplasmic CD138 staining in stromal cell in KCOT. G) H\&E stained section of RC. H) Strong membranous CD138 expression in all epithelial cells with basal cell accentuation, and weak cytoplasmic CD138 staining in stromal cell in RC (H\&E and immunohistochemical stains; $\mathrm{x} 100$ for C-H panels; x200 for A and B panels).

\section{REFERENCES}

1. Altieri DC. Survivin, versatile modulation of cell division and apoptosis in cancer. Oncogene. 2003;22:8581-9.

2. Chau GY, Lee AF, Tsay SH, Ke YR, Kao HL, Wong FH, Tsou AP, Chau YP. Clinicopathological significance of survivin expression in patients with hepatocellular carcinoma. Histopathology. 2007;51:204-18.

3. Chen WC, Liu Q, Fu JX, Kang SY. Expression of survivin and its significance in colorectal cancer. World J Gastroenterol. 2004:10:2886-9.

4. Falleni M, Pellegrini C, Marchetti A, Oprandi B, Buttitta F, Barassi F, Santambrogio L, Coggi G, Bosari S. Survivin gene expression in early-stage non-small cell lung cancer. J Pathol. 2003;200:620-6.
5. Osaka E, Suzuki T, Osaka S, Yoshida Y, Sugita H, Asami S, Tabata K, Hemmi A, Sugitani M, Nemoto N, Ryu J. Survivin as a prognostic factor for osteosarcoma patients. Acta Histochem Cytochem. 2006;39:95-100.

6. Sarela AI, Verbeke CS, Ramsdale J, Davies CL, Markham AF, Guillou PJ. Expression of survivin, a novel inhibitor of apoptosis and cell cycle regulatory protein, in pancreatic adenocarcinoma. Br J Cancer. 2002;86:886-92.

7. Zamparese R, Pannone G, Santoro A, Lo Muzio L, Corsi F, Pedicillo MC, Scillitani EL, Tortorella S, Staibano S, Piscuoglio S, Lo Russo L, Bufo P. Survivin expression in renal cell carcinoma. Cancer Invest. 2008;26:929-35. 
8. Kumamoto H, Ooya K. Expression of survivin and X chromosomelinked inhibitor of apoptosis protein in ameloblastomas. Virchows Arch. 2004;444:164-70.

9. Andric M, Dozic B, Popovic B, Stefanovic D, Basta-Jovanovic G, Djogo N, Andjus P, Milasin J. Survivin expression in odontogenic keratocysts and correlation with cytomegalovirus infection. Oral Dis. 2010;16:156-9.

10. Tang A, Amagai M, Granger LG, Stanley JR, Udey MC. Adhesion of epidermal Langerhans cells to keratinocytes mediated by E-cadherin. Nature. 1993;361:82-5.

11. Kohl K, Klein E, Koch S, Schnautz S, Bieber T. Migration and differentiation of Langerhans cell precursors. Eur J Cell Biol. 2004;83:805-11.

12. Gabbert HE, Mueller W, Schneiders A, Meier S, Moll R, Birchmeier W, Hommel G. Prognostic value of E-cadherin expression in 413 gastric carcinomas. Int J Cancer. 1996;69:184-9.

13. Lipponen P, Saarelainen E, Ji H, Aaltomaa S, Syrjänen K. Expression of E-cadherin (E-CD) as related to other prognostic factors and survival in breast cancer. J Pathol. 1994;174:101-9.

14. Bringuier PP, Umbas R, Schaafsma HE, Karthaus HF, Debruyne FM, Schalken JA. Decreased E-cadherin immunoreactivity correlates with poor survival in patients with bladder tumors. Cancer Res. 1993;53:3241-5.

15. Mattijssen V, Peters HM, Schalkwijk L, Manni JJ, van 't HofGrootenboer B, de Mulder PH, Ruiter DJ. E-cadherin expression in head and neck squamous-cell carcinoma is associated with clinical outcome. Int J Cancer. 1993;55:580-5.

16. Hubert P, Bousarghin L, Greimers R, Franzen-Detrooz E, Boniver J, Delvenne P. Production of large numbers of Langerhans' cells with intraepithelial migration ability in vitro. Exp Dermatol. 2005;14:469-77.

17. Galan A, Ko CJ. Langerhans cells in squamous cell carcinoma vs. pseudoepitheliomatous hyperplasia of the skin. J Cutan Pathol. 2007;34:950-2.

18. Mello LA, Figueiredo AL, Ramos EA, Gurgel CA, Martins MD, de Figueiredo CR, Cury PR, de Albuquerque Júnior RL, Ramalho LM, Santos JN. CDla-positive Langerhans cells and their relationship with E-cadherin in ameloblastomas and keratocystic odontogenic tumors. J Oral Pathol Med. 2013;42:454-61.

19. Chu PG, Arber DA, Weiss LM. Expression of T/NK-cell and plasma cell antigens in nonhematopoietic epithelioid neoplasms. An immunohistochemical study of 447 cases. Am J Clin Pathol. 2003;120:64-70.

20. O’Connell FP, Pinkus JL, Pinkus GS. CD138 (syndecan-1), a plasma cell marker immunohistochemical profile in hematopoietic and nonhematopoietic neoplasms. Am J Clin Pathol. 2004;121:25463.

21. Mennerich D, Vogel A, Klaman I, Dahl E, Lichtner RB, Rosenthal A, Pohlenz HD, Thierauch KH, Sommer A. Shift of syndecan-1 expression from epithelial to stromal cells during progression of solid tumours. Eur J Cancer. 2004;40:1373-82.
22. Gökden N, Greene GF, Bayer-Garner IB, Spencer HJ, Sanderson RD, Gökden M. Expression of CD138 (Syndecan-1) in renal cell carcinoma is reduced with increasing nuclear grade. Appl Immunohistochem Mol Morphol. 2006;14:173-7.

23. Ozcan A, Celik E, Karslioğlu Y, Basal S. CD138 expression in renal tumors and its usage in the differential diagnosis. Turkish Journal of Pathology. 2011;27:110-5.

24. Al-Otaibi O, Khounganian R, Anil S, Rajendran R. Syndecan-1 (CD 138) surface expression marks cell type and differentiation in ameloblastoma, keratocystic odontogenic tumor, and dentigerous cyst. J Oral Pathol Med. 2013;42:186-93.

25. Matutes E. New additions to antibody panels in the characterisation of chronic lymphoproliferative disorders. J Clin Pathol. 2002;55:180-3.

26. Orciani M, Trubiani O, Guarnieri S, Ferrero E, Di Primio R. CD38 is constitutively expressed in the nucleus of human hematopoietic cells. J Cell Biochem. 2008;105:905-12.

27. de Oliveira MG, Lauxen Ida S, Chaves AC, Rados PV, Sant'Ana Filho M. Odontogenic epithelium: Immunolabeling of Ki-67, EGFR and survivin in pericoronal follicles, dentigerous cysts and keratocystic odontogenic tumors. Head Neck Pathol. 2011;5:1-7.

28. Bologna-Molina R, Mosqueda-Taylor A, Lopez-Corella E, Almeida OP, Carrasco-Daza D, Garcia-Vazquez F, FarfanMorales JE, Irigoyen-Camacho ME, Damián-Matsumura P. Syndecan-1 (CD138) and Ki-67 expression in different subtypes of ameloblastomas. Oral Oncol. 2008;44:805-11.

29. Nadalin MR, Fregnani ER, Silva-Sousa YT, Perez DE. Syndecan-1 (CD138) and Ki-67 expression in odontogenic cystic lesions. Braz Dent J. 2011;22:223-9.

30. Lo Muzio L, Farina A, Rubini C, Pezzetti F, Stabellini G, Laino G, Santarelli A, Pannone G, Bufo P, de Lillo A, Carinci F. Survivin as prognostic factor in squamous cell carcinoma of the oral cavity. Cancer Lett. 2005;225(1):27-33.

31. Engels K, Knauer SK, Metzler D, Simf C, Struschka O, Bier C, Mann W, Kovács AF, Stauber RH. Dynamic intracellular survivin in oral squamous cell carcinoma: Underlying molecular mechanism and potential as an early prognostic marker. J Pathol. 2007;211:532-40.

32. Preuss SF, Weinell A, Molitor M, Semrau R, Stenner M, Drebber U, Wedemeyer I, Hoffmann TK, Guntinas-Lichius O, Klussmann JP. Survivin and epidermal growth factor receptor expression in surgically treated oropharyngeal squamous cell carcinoma. Head Neck. 2008;30:1318-24.

33. Davies EJ, Blackhall FH, Shanks JH, David G, McGown AT, Swindell R, Slade RJ, Martin-Hirsch P, Gallagher JT, Jayson GC. Distribution and clinical significance of heparan sulfate proteoglycans in ovarian cancer. Clin Cancer Res. 2004;10:517886. 